\title{
起立と着座が容易な自動車シートの開発*
}

\section{大谷光司**, 山崎信寿***}

\begin{abstract}
To reduce the workload of intermittent driving like a parcel delivery service driver, new automobile seat for low-speed and short time use was proposed. Easiness of standing-up and seating comfort during driving were compared by 13 male among three seat conditions : short bottom, tilt bottom, and bent bottom. As a result, it was found that the suitable bottom shape is the bent bottom which is composed with level hip part and tilt thigh part, and the maximum bottom height is $65 \%$ of the subject's crotch height. The bottom height was limited from pressure concentration on the hipbone and slip of the hip. The preferable seat shape for 11 male and 10 female was adjusted by using the experimental chair, which its seat surface shape divided into freely adjustable 16 plates. The preferred condition was as follows: depth of the hip part is $8 \mathrm{~mm}$, the frontal thigh part tilt 24 degrees, the backrest angle is 75 degrees from the horizontal line, and the height of convexo-lumbar part is $15 \mathrm{~mm}$. The preferred connecting point between hip part and frontal thigh part was near the gluteal furrow, where its body surface is flexible and relatively insensitive to pressure. Although the proposed seat condition requires another controller as a substitution of the pedal, it is possible to keep comfortable sitting about 30 minutes, and can reduce about $30 \%$ of the muscle load in stand-up motion compared with the conventional automobile seat.
\end{abstract}

宅配便の運転手のように，起立と着座を頻繁に繰り返す断続的運転のための新たな低速・短時間用自動 車シートを提案した。男性 13 名について, 立ち上がりやすく, かつ, 運転操作時の着座の快適性を許容で きる身体支持方法を探索した結果，䌓部を水平にし，大腿部のみを傾斜させた座面が有効であり，その許 容最大座面高は，圧力集中と尻滑りの制約から，股下高の $65 \%$ であることがわかった．また，支持面を 16 分割した実験椅子を用い, この高さ条件で男性 11 名，女性 10 名の好みの支持面形状を求めた. その結果,

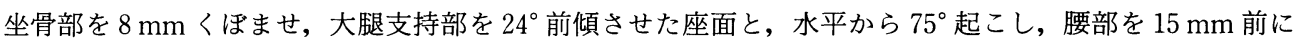
出した背もたれ形状が適していた，座面の傾斜開始点は，変形しやすく圧迫感度が鈍い碃溝付近が好まれ た。この設計条件によるシートは, ペダル操作に代わる新たな制御装置を必要とするが, 30 分程度なら快 適着座状態を保て, 従来の自動車シートと比較して立ち上がり動作の筋負担の 3 割程度を軽減できる. (キーワード : 椅子, 自動車シート, 着座動作, 起立動作, 高座面椅子)

\section{1. はじめに}

都市部における宅配便の運転手は, 平均 $15 \mathrm{~km} / \mathrm{h}$ 以 下の低速で断続的に短時間走行し1)，一日 100 回以上乗 り降りを行う2).また，銀行などの空口業務では，短時 間で立ち座りを繰り返すことが多い.

このような断続的着座作業用椅子については，古くは

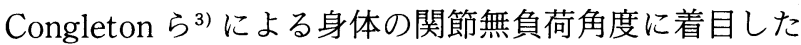
高座面の外科手術用椅子があり，その腰部負担軽減効果 が示されている．また，高座面の椅子は従来，立位で行

* 受付：2006 年 11 月 14 日 受理：2007年 6 月 7 日

** 慶應義塾大学理工学研究科

Graduate School of Sci. \& Tech., Keio University

*** 慶應義塾大学理工学部機械工学科

Faculty of Sci.\& Tech., Keio University
われていた工場内軽作業現場への導入も試みられてお り，下腿の血流量4) やむくみ量5) などにその有効性が示 されている.しかし，これらの断続的作業用椅子の多く は短い座面で臀部のみを支持し，背もたれがないため， 全体重の 8 割程度を智部の接触面のみで受ける座り心地 の悪いものであった．また，高座面椅子を自動車に応用 すると6)，下肢による体重支持割合が増加するため，ぺ ダルによるアクセルやブレーキ操作が困難になるという 問題もあった。

このため, 本研究では運転操作系の問題は今後の技術 課題とし，起立と着座を頻繁に行うことへの対策を重点 に, 着座の快適性と乗降の容易さの両方を満足させる自 動車用高座面シートを提案した。 


\section{2. 身体支持方法の検討}

起立と着座は座面高が高いほど容易に行えるが7), 着 座状態での快適性は高座面になると低下する ${ }^{8)}$ 。このた め本章では，大腿が前傾するまで高くした図 1 の三つの 座面について，着座の快適化の可能性を検討した。

(1) 座面全体を大腿に沿うように前傾させる（以下，傾 斜座面).

(2) 水平な短座面で臀部のみを支持する（以下，短座 面).

（3）臂部を水平短座面とし，大腿部を前傾させる（以 下, 中折座面).

これらの座面条件を, 図 2 に示す剛体平板に厚さ 20 $\mathrm{mm}$ のウレタンクッションを貼り付けた実験椅子と フットレストで実現し, 表 1 (a)に示す男性 4 名に着座さ せた.なお，表 1 の被験者はすべて普通運転免許保持者 である. 3 条件の坐骨結節点高さは, 作業用高座面椅子 （例：タカラベルモント製 DR-002 MK）の座面高を参 考に $550 \mathrm{~mm}$ とし, 臂部支持面長, 背もたれ面と大腿 支持面の角度およびフットレストの位置と角度を，図 2 に示す実線矢印方向に自由に調節し, 快適化させた。

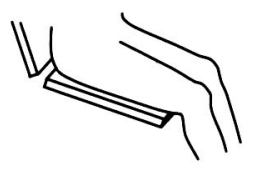

傾斜座面

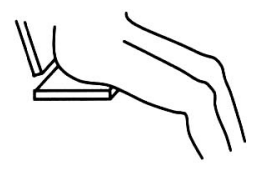

短座面

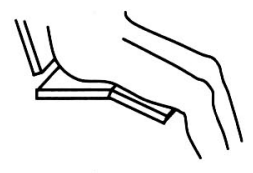

中折座面
図 1 座面形式

Fig. 1 Seat surface types.
着座姿勢は, 図 3 に示す身体特徵点を空間座標計測装 置（小坂研究所製 VSC-27 A) で計測した。着座時に背 もたれと接触する第 1 胸椎点, 第 10 胸椎点, および仙 骨点の位置は, 胸郭節と骨盤節の形状が姿勢によって変 わらないものと仮定し, 背もたれのない椅子に着座した ときに計測した体幹標点位置を, 背もたれ使用時の体幹 前面標点位置と重ね合わせることで推定した。 また，着 座時の筒部の支持面反力とフットレスト反力を床反力計 （共和電業製 EFP-S-1.5 KN SA 13）で計測し，床反力 と着座姿勢から膝関節モーメントと足関節モーメントを 算出した。下肢の節質量は被験者の体重から推定し ${ }^{9)}$, 䩲帯などによる関節抵抗モーメントは着座姿勢が中立姿 勢10)に近いため無視した.

表 2 に示すように，中折座面では座面せん断力とフッ トレスト反力がともに小さく, 身体支持のための膝と足 関節のモーメントも小さくなっている。これは, 座面水 平部で尻滑りを抑え，傾斜部で大腿を支持するためであ

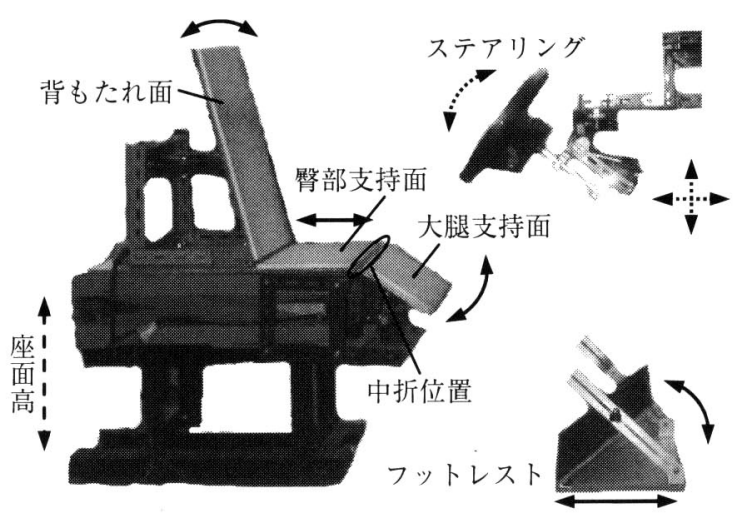

図 2 実験装置と調節箇所

Fig. 2 Experimental set and adjustable parts.

表 1 被験者属性

Tab. 1 Characteristics of subjects.

\begin{tabular}{|c|c|c|c|c|c|c|c|}
\hline 実験項目 & 性 & 年齢［歳］ & 人数 & 身長 [mm] & 体重 $[\mathrm{kg}$ ] & 股下高 $[\mathrm{mm}]$ & 被験者の重なり \\
\hline (a)身体支持方法の探索 & 男 & $22 \sim 23.3 \sim 24$ & 4 & $1,645 \sim 1,681 \sim 1,712$ & $55.0 \sim 59.2 \sim 67.0$ & $744 \sim 795 \sim 840$ & (b), (c) と 4 名 \\
\hline $\begin{array}{l}\text { (b) 着座許容最大座面高 } \\
\text { の探索 }\end{array}$ & 男 & $22 \sim 23.3 \sim 24$ & 13 & $1,640 \sim 1,716 \sim 1,795$ & $55.0 \sim 60.9 \sim 84.8$ & $744 \sim 807 \sim 861$ & $\begin{array}{l}\text { (a) と } 4 \text { 名, } \\
\text { (c) と } 6 \text { 名 }\end{array}$ \\
\hline \multirow{2}{*}{$\begin{array}{l}\text { (c) 身体支持面形状 } \\
\text { の高適合化 }\end{array}$} & 男 & $22 \sim 22.6 \sim 24$ & 11 & $1,640 \sim 1,687 \sim 1,795$ & $54.0 \sim 62.2 \sim 70.5$ & $736 \sim 788 \sim 840$ & $\begin{array}{l}\text { (a) と } 4 \text { 名, } \\
\text { (b) と } 6 \text { 名 }\end{array}$ \\
\hline & 女 & $20 \sim 22.5 \sim 27$ & 10 & $1,497 \sim 1,566 \sim 1,652$ & $44.0 \sim 49.2 \sim 56.0$ & $682 \sim 732 \sim 761$ & なし \\
\hline $\begin{array}{l}\text { (d) 体表面柔軟性と } \\
\text { 圧迫感度の計測 }\end{array}$ & 男 & $22 \sim 22.3 \sim 24$ & 4 & $1,622 \sim 1,690 \sim 1,791$ & $51.0 \sim 56.9 \sim 66.0$ & $738 \sim 765 \sim 791$ & なし \\
\hline \multirow{2}{*}{ (e) 着座感の評価 } & 男 & $21 \sim 22.0 \sim 23$ & 4 & $1,632 \sim 1,708 \sim 1,831$ & $50.0 \sim 55.8 \sim 67.0$ & $749 \sim 786 \sim 825$ & なし \\
\hline & 女 & $21 \sim 24.0 \sim 27$ & 3 & $1,593 \sim 1,610 \sim 1,652$ & $49.0 \sim 52.0 \sim 56.0$ & $728 \sim 746 \sim 761$ & なし \\
\hline (f) 乗降動作負担の評価 & 男 & $22 \sim 22.7 \sim 24$ & 3 & $1,638 \sim 1,688 \sim 1,743$ & $50.0 \sim 51.7 \sim 54.0$ & $764 \sim 783 \sim 818$ & なし \\
\hline
\end{tabular}




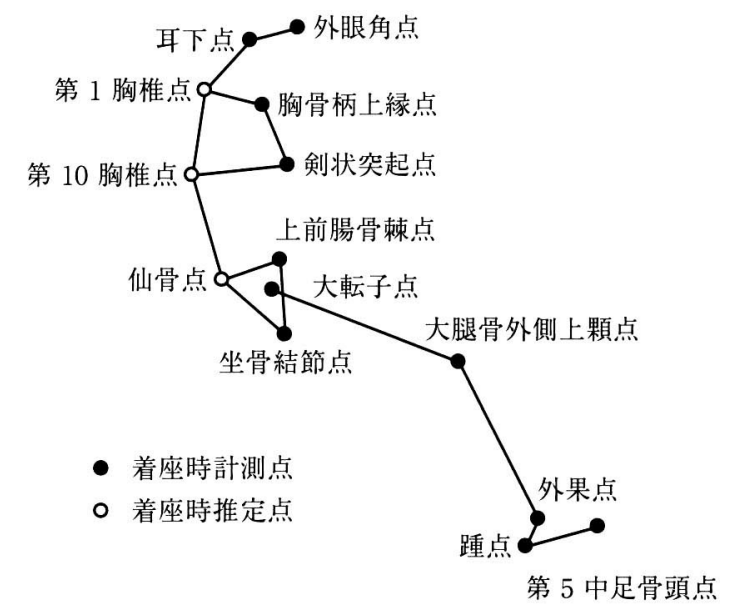

図 3 着座姿勢の計測点と計測例（中折座面）

Fig. 3 Posture measuring point and example of sitting posture (bent bottom).

表 2 各支持方法の反力と関節モーメント

Tab. 2 Reaction force and joint moment by each seat surface type.

\begin{tabular}{|c|c|c|c|}
\hline 評価項目 & 傾斜 & 短座 & 中折 \\
\hline $\begin{array}{r}\text { 座面せん断力 } \\
{[\mathrm{N}]}\end{array}$ & $37 \sim 58 \sim 83$ & $29 \sim 37 \sim 56$ & $17 \sim 29 \sim 37$ \\
\hline $\begin{array}{l}\text { フットレス反 } \\
\text { カ }[\mathrm{N}]\end{array}$ & 191 195 202 & $93 \sim 117 \sim 133$ & $67 \sim 80 \sim 98$ \\
\hline $\begin{array}{l}\text { 足関節モーメ } \\
\text { ント }[\mathrm{Nm}]\end{array}$ & $2.2 \sim 3.0 \sim 4.1$ & $1.9 \sim 2.5 \sim 4.0$ & $1.2 \sim 1.8 \sim 3.1$ \\
\hline $\begin{array}{l}\text { 滕関節モーメ } \\
\text { ント }[\mathrm{Nm}]\end{array}$ & $11.2 \sim 10.3 \sim 14.2$ & $3.4 \sim 5.3 \sim 8.0$ & $3.0 \sim 4.1 \sim 6.9$ \\
\hline
\end{tabular}

最小〜平均〜最大

る.このため, 本研究では中折座面を基本形状とし, そ の最適化を行った.

\section{3. 着座許容最大座面高の探索}

図 2 に示す実験装置に, 表 1 (b)の男性被験者 13 名を 着座させ, 着座を許容できる座面高の範囲を探索した. 座面高は被験者股下高の 55～75\%を 5\%刻みで 5 段階に 設定し, 設定順序は順序効果を考慮して被験者ごとに異 なるものとした.

被験者には, 都市部での走行を想定して, 眼点から 3 $\mathrm{m}$ 前方の標点の注視と, 持ち替え動作を含む左右 1 回 転以上のステアリング操作を指示し, 図 2 の座面高を除 く実線および点線矢印計 8 筒所を自由に調節させて快適 化させた。また，2 章と同様に各座面高における着座姿 勢と座面およびフットレストの反力を計測し，さらに， 座面圧力分布 (ニッタ製 BIGMAT) の計測と, 着座時

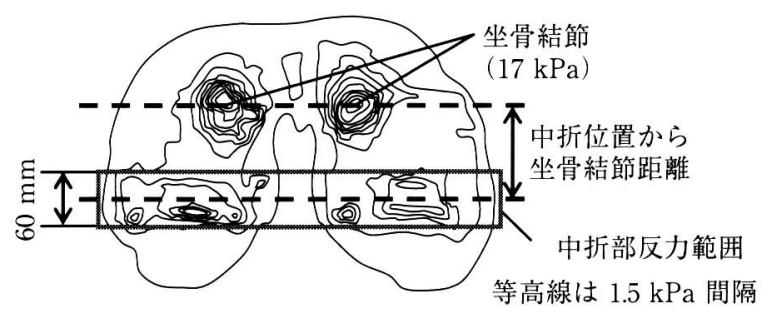

図 4 座面圧力の計測例（座面高/股下高=65\%）

Fig. 4 Example of measured pressure at the buttocks.

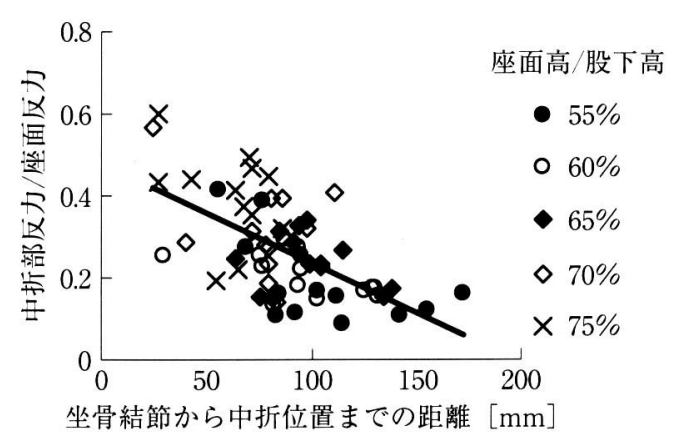

図 5 坐骨結節位置と中折部反力割合の関係

Fig. 5 Relationship between tuber ischiadicum position and reaction rate at the seat bending point.

の快適性および立ち上がりやすさに関する 7 段階の官能 検査を口頭質問形式で行った。評価軸は，圧迫感や滑り

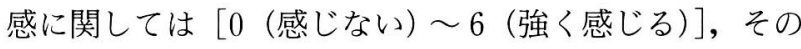
他に関しては $[-3($ 悪い) 〜0（どちらでもない）～ 3 (良い) ］とし，尺度への影響に配慮して「やや」など の語句は用いなかった。

圧力分布の計測例を図 4 に示す. 座面圧力にセル面積 $\left(17 \mathrm{~mm}^{2}\right)$ をかけた総和を座面反力とし, 中折位置の前 後 $30 \mathrm{~mm}$ の範囲の反力を, 中折部反力とした。座面高 に対する着座位置と中折部反力の関係を図 5 に示す. 座 面高が股下高の $70 \%$ 以上では, 着座位置が前方へ移動 して坐骨結節位置が中折位置に近づき, 座面反力に対す る中折部反力の割合が増加して不快となった。また図 6 に示すように，座面のせん断力は股下高の $70 \%$ 以上の 高座面になると有意に増加し, 臂部の滑り感も増加し た.この結果, 図 7 に示すように総合的な着座快適性 は，座面高が股下高の $65 \%$ より高くなると悪化した。 一方，立ち上がりやすさは，座面が高くなるほど向上し た。

以上より, 着座を許容できる最大座面高は, 着座者股 下高の $65 \%$ とした．日本人青年男性 95 パーセンタイル から青年女性 5 パーセンタイル11) を満足する座面高の 範囲は，556〜 475 mm になる。これは，座面高が比較 的高い現状のミニバンクラスのシートよりさらに250〜 


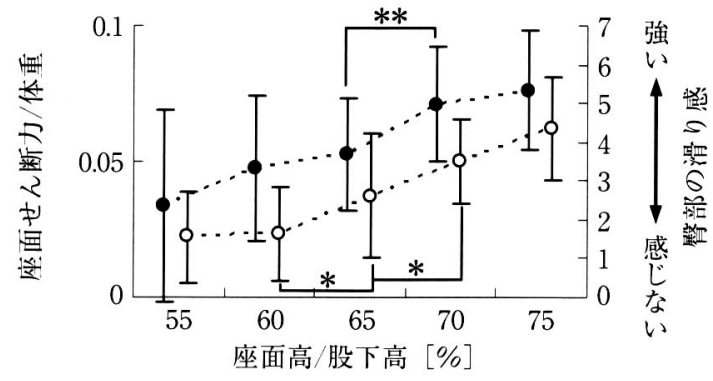

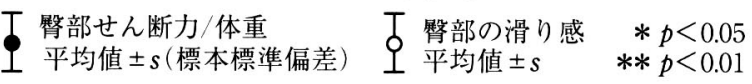

図 6 臀部せん断力と层部の滑り感

Fig. 6 Shear stress and slip feeling at the buttocks.
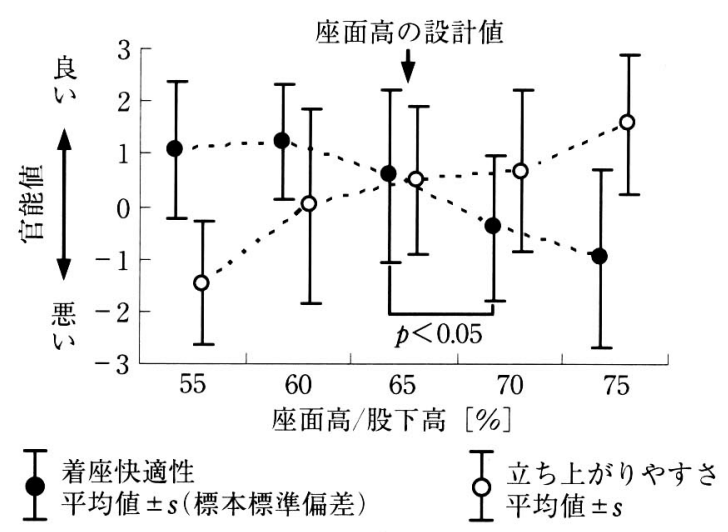

図 7 着座快適性と立ち上がりやすさの関係

Fig. 7 Trade-off of sitting comfort and easiness of standing up.

$170 \mathrm{~mm}$ 程度高い.

\section{4. 身体支持面形状の高適合化}

\section{4-1. 実験方法}

図 8 に示す, 形状および支持面のばね定数を自由に調 節できる実験椅子 ${ }^{12)}$ と床面昇降機を用い, 好みの支持 面形状を探索した。実験椅子の背もたれは縦幅 $70 \mathrm{~mm}$ で 10 分割, 座面は $60 \mathrm{~mm}$ で 6 分割されている. 各面 は横幅 $550 \mathrm{~mm}$ で長軸回りに自由に回転し, 身体形状 に追従する．また支持面の沈み込み量と，支持面に加わ る圧縮およびせん断荷重を計測することができる。

支持面上には, 主として断熱のために, 厚さ $8 \mathrm{~mm}$ の薄手マットを敷いた。また, 床面昇降機上の床反力計 に角度可変のフットレストを固定し，スタンドタイプの リフターにステアリング型コントローラ（ロジクール製 GT-FORCE，把持部 $\phi 380$ に交換）を取り付け，ブ レーキとアクセルペダルをフットレスト面と同一角度に

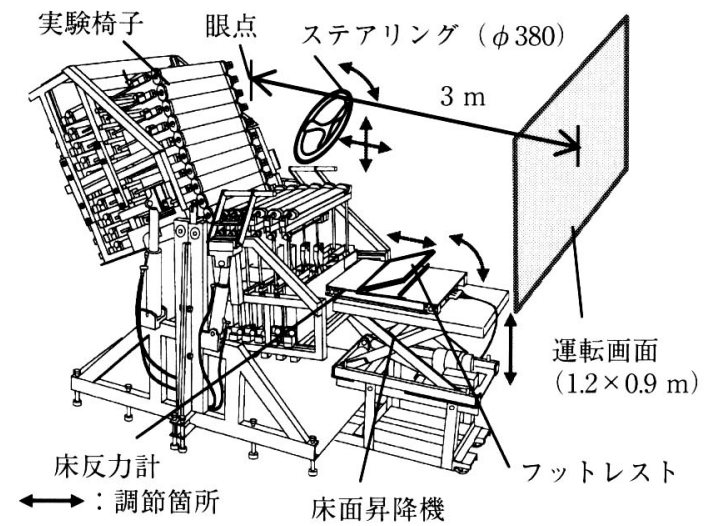

図 8 支持条件探索のための実験装置

Fig. 8 Experimental apparatus.

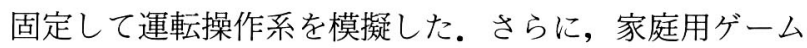
機（ソニー製 PlayStation 2）と専用ソフト（ソニー製 Granturismo Concept）およびプロジェクターを用い， 眼点から前方 $3 \mathrm{~m}$ 亿位置するスクリーン $(1.2 \mathrm{~m} \times 0.9$ m）に運転画面を投影した。

表 1 (c)に示す男性被験者 11 名については，3 章の実 験で求めた好みの椅子寸法と角度を初期条件とし，上半 身は非着衣，下半身はスパッツとして着座させた。ま た，女性被験者 10 名については，男性被験者が調節し

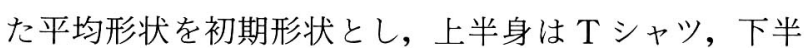
身はショートパンツで着座させた。なお，被験者は日本 人青年男性 95 パーセンタイルから青年女性 5 パーセン タイルの身長を満足するものである.クッションは好み の最終安定形状に影響しないことから ${ }^{13)}$ ，各支持面ばね 定数は硬めの $60 \mathrm{~N} / \mathrm{mm}$ とした。また，座面高は被験者 の坐骨結節高が股下高の $65 \%$ になるように床面昇降機 で調節した。

以上の条件に扔いて，姿勢保持と持ち替え動作を含む 左右 1 回転以上のステアリング操作が容易にできるよう に，ステアリングおよびペダルとフットレストの位置と 角度を自由に調節させ，次にステアリング把持姿勢のま まシート形状を満足するまで調節させた。シート形状調 節後に，ドライビングゲームによる 10 分間の模擬運転 を行わせ，この間に不快に感じた箇所を再調節させた。 ステアリングへの不満はなく，ペダルは踏み込みにくい との意見があった。

運転終了後, 着座姿勢とシート形状，反力分布，ステ アリングとフットレストの位置を計測した。シート形状 と反力分布の計測例を図 9 に示す。シート形状は，各支 持面の回転中心位置を三次スプライン曲線で補間して示 した。シート形状調節後には，腰部の段差と腎部の凹み が形成され，反力が分散されていることがわかる. 


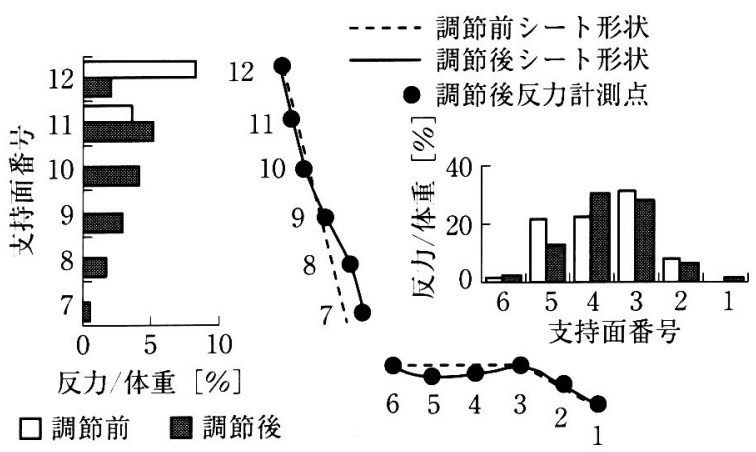

図 9 シート形状と垂直反力の計測例

Fig. 9 Measured reaction force and seat line.

\section{4-2．座面形状と決定要因}

座面形状の計測結果と設計値を図 10 に示す. 座面中 折位置と, シートヒンジポイントを結ぶ線は水平で，こ の線からの熋部凹み量は平均 $8 \mathrm{~mm}$ であり, 性差はな かった．腎部の最凹位置は，反力が集中する坐骨結節部 と一致し，図11のように骨盤を後傾させるほど坐骨結 節はヒンジポイントから遠ざかる．着座者の好みの骨盤 角度に対応するために，臂部支持面は坐骨結節位置の被 験者平均 $93.5 \mathrm{~mm}$ に標準偏差を加減して，ヒンジポイ ントから 78～109 mm の範囲とし，この区間を全体に 8 $\mathrm{mm}$ 下げ，その前後を骬らかな曲線で結ぶ形状とした。

腎部と大腿の中間に位置する座面中折部には，圧力が 集中しやすい。この不快感を軽減するために，表 1 (d)の 男性 4 名について智大腿表面の柔軟性と圧迫感度を計測 した。計測姿勢は座面高を股下高の $65 \%$ にしときの 自然座位とし，図 2 のシートを用いて背部および左誆大 腿部のみを支持した。また，図 12 (a)に示すように，右 慰大腿部の坐骨結節点と膝窩点を結ぶ線上に，坐骨結節 点から約 $30 \mathrm{~mm}$ 間隔で計測点を 6 点とった。

体表面の柔軟性の計測には，押し込み硬さ計（特殊計 測製 TK $03 \mathrm{C}$ ，押し当て部 $\phi 6$ ）を用いた。押し当て部 を体表面に押し込んだときの荷重 $y[\mathrm{~N}]$ 一変位 $x[\mathrm{~mm}]$ 曲線は，図 12 (b)のような非線形性を示す。このため, 式(1)で指数近似したときの係数 $k\left[\mathrm{~mm}^{-1}\right]$ を体表面柔軟 性と定義した。

$$
y=0.01 \exp (k x)
$$

圧迫感度の計測には， $\phi 60$ の半円柱を横にして取り 付けた荷重計（特殊計測製 K 102 A）を用いた。押し込 み体の寸法は, 大腿表面の二点弁別閾14) から定めた。 膝窩点から坐骨方向に $50 \mathrm{~mm}$ の位置を基準点とし，基 準点に加えた荷重 $F_{1}[\mathrm{~N}]$ と，他の計測点 6 点に同じ圧 迫感になるまで加えた荷重 $F_{2}[\mathrm{~N}]$ から, Stevens のべ

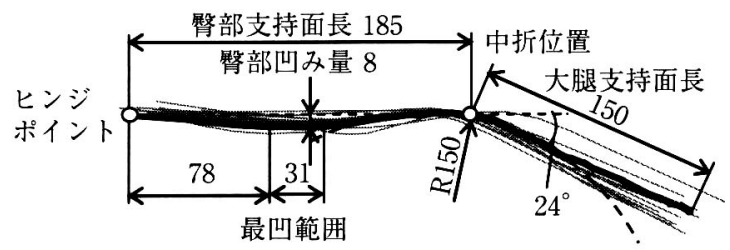

図 10 座面形状の設計值

Fig. 10 Design of the seating surface geometry.

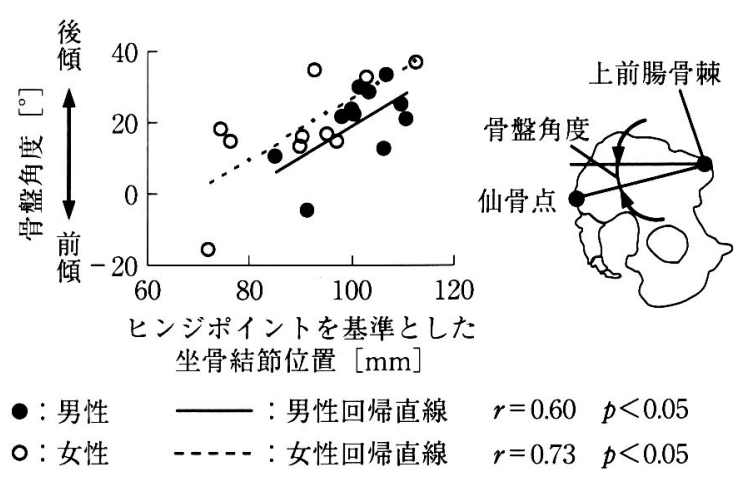

図 11 坐骨結節位置と骨盤角度の関係

Fig. 11 Relationship between tuber ischiadicum position and pelvis angle.

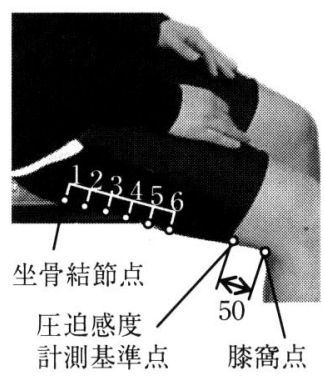

(a) 計測点

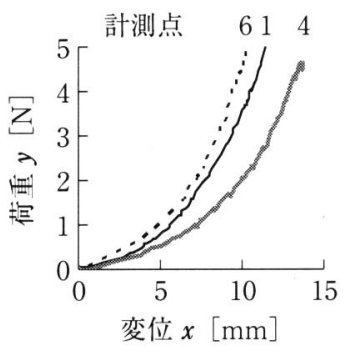

(b) 計測例
図 12 大腿下面柔軟性の計測

Fig. 12 Hardness of thigh surface.

キ関数の法則 ${ }^{15}$ を参考に，圧迫感度を式(2)で定義した。 圧迫感度 $=F_{1} / F_{2}^{1.1}$

図 13 亿示すように臂大腿表面の柔軟性は, 坐骨結節 点から約 $90 \mathrm{~mm}$ 前方の臂溝付近で最も柔らかくなっ た。慰部でやや硬い特性を示すのは，股関節周りの筋に 上ると考えられる。一方, 圧迫感度は膝窩から瑿溝に近 づくほど鈍くなる。このため, 中折位置は謷溝に近い坐 骨結節点から $90 \mathrm{~mm}$ 前方とし，シートヒンジポイント からの平均坐骨結節位置 $93.5 \mathrm{~mm}$ を加えて $185 \mathrm{~mm}$ ま でを腎部支持面長とした。これは，中折位置のゆるやか な $\mathrm{R}$ 形状を考慮すれば，表 1 (c)の被験者 21 名の好みの 腎部支持面長平均値 $192 \mathrm{~mm}$ とほぼ一致する。 

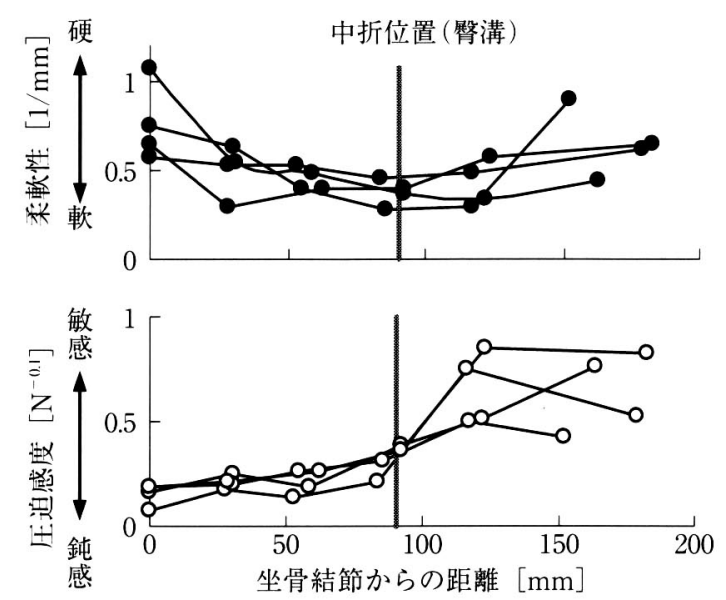

図 13 臂大腿面の柔軟性と圧迫感度

Fig. 13 Hardness and pressure sensitivity of thigh surface.

\section{4-3. 背もたれ形状と決定要因}

好みの背もたれ形状の計測結果と設計值を図 14 に示 す. 平均形状は, $15 \mathrm{~mm}$ の段差をもつ水平加ら $75^{\circ}$ の 2 枚の平板を仙骨上方から第 10 胸椎点下方までなだらか につないだ形になっている. 平行部の長さは, 第 10 胸 椎点と仙骨点位置の個体差の範囲で定めた。 また, 運転 中の胸郭が直立しているために, 第 10 胸椎点より上部 は背もたれに接触しなかった。このときの胸郭角度（第 1 胸椎点と第 10 胸椎点を結ぶ直線と水平線のなす角度） は $87 \pm 4.1^{\circ}$ で, 自然立位時 $85 \pm 2.9^{\circ}$ とほぼ等しい角度 であったことから，この背もたれ条件で自然に前方を注 視できる姿勢になっていると考えられる.

腰部の $15 \mathrm{~mm}$ の段差は, 接触式背面形状計測装置 ${ }^{16)}$ で求めた図 15 に示す腰部前湾量の 4 割程度の大きさで あった。図中×印で示した背もたれをより後傾させた被 験者 3 名については, 再実験を行った結果, 図 14 の背 もたれ条件で満足することを確認した。

\section{4-4．操作系配置と決定要因}

図 16 に示すように，シートのヒンジポイントを基準 とした好みの操作器配置は, 鉛直方向位置と水平方向位 置の間で高い相関が得られた。これは，図 17 に示すよ うにステアリングとシートを直線状にスライドさせるこ とで個体差に対応できることを示している。このときの 運転姿勢は図 18 のようになった。この姿勢は無重力時 の脱力姿勢 ${ }^{10)}$ に近く，被験者は関節が中立位置になる ようにシートや操作系位置を調節していることがわか る.なお,このときの肩の屈曲角度は $49 \pm 4.2^{\circ}$, 肘の 屈曲角度は $110 \pm 15.3^{\circ}$ であり, あらかじめ計測した従

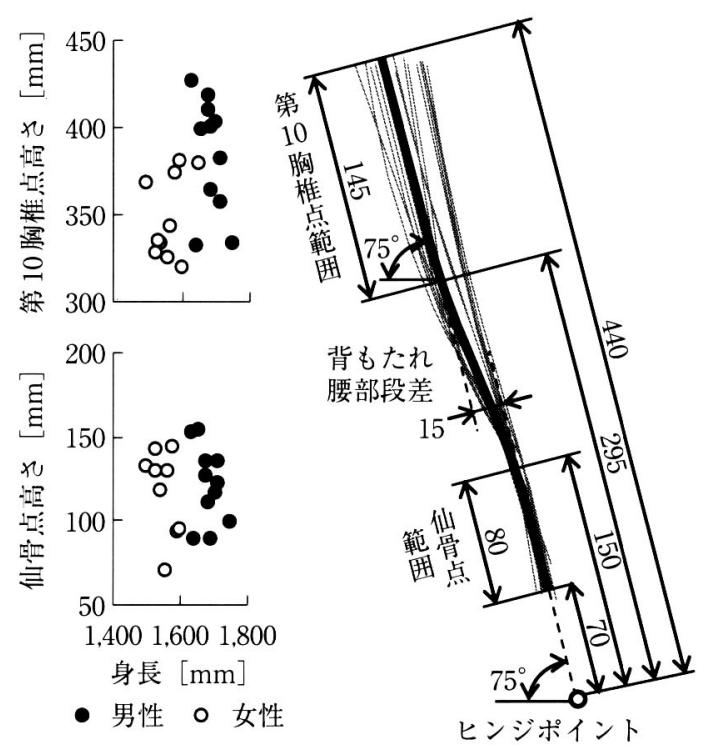

図 14 背もたれ形状の設計值

Fig. 14 Design of the seat back geometry.

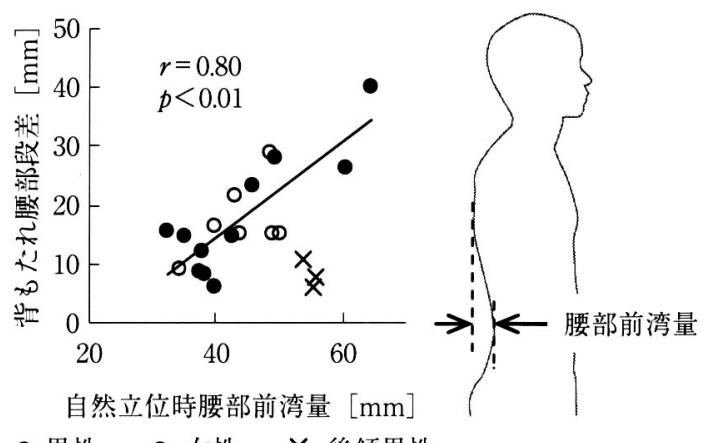

- 男性 ○ 女性 $\times$ 後傾男性

図 15 背もたれ形状と身体背面形状の関係

Fig. 15 Relationship between seat back convex and human back shape.
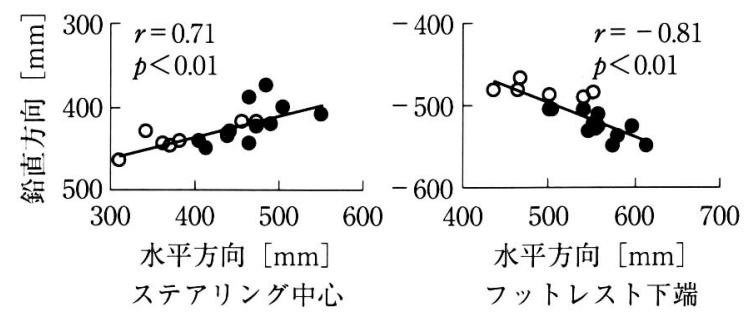

- 男性 ○女性

図 16 ヒンジポイントを基準とした好みの操作器配置

Fig. 16 Operation device arrangement on the basis of the hinge point.

来運転姿勢のそれぞれ $49 \pm 3.6^{\circ}$ と $114 \pm 13.4^{\circ}$ にほぼ一 致した。したがって，ステアリングに関しては従来と同 等の操作性が得られていると考えられる.

被験者の好みの下腿角度は従来姿勢よりも立位に近い 


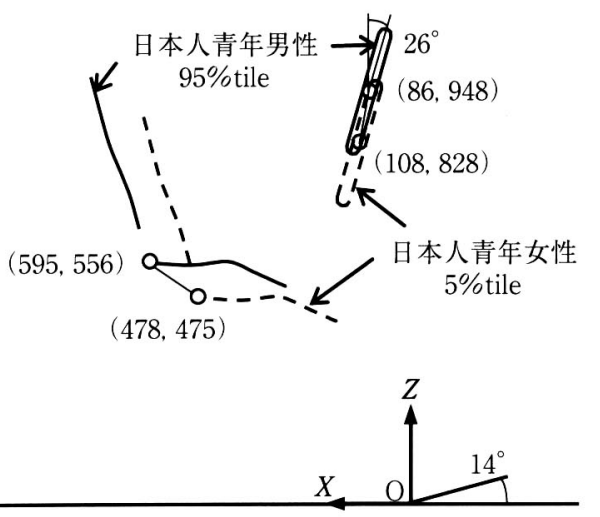

図 17 シートとステアリングのスライド量

Fig. 17 Adjusting range of seat and steering.

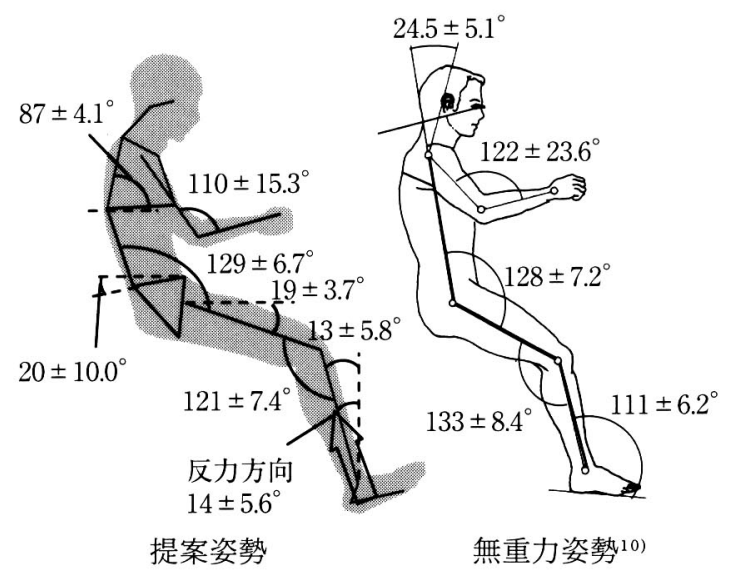

図 18 提案シートでの運転姿勢

Fig. 18 Driving posture taken by the proposed seat.

$13 \pm 5.8^{\circ}$ となり, フットレストの反力方向とほぼ一致 した。これは下肢で体重の15\%程度を支えているため である。ただし, フットレスト反力の着力点はほぼ下腿 軸とフットレストの交点付近にあるために，反力による 足関節抒よび膝関節まわりのモーメントはほぼ 0 にな る.したがって, フットレストの位置と方向は, 着座時 の㯟㧍よび足関節負荷が最小になるように決定されてい ると考えられる。提案姿勢では下腿で体重の一部を支 え，かつ踏み込み時に足関節が下腿と直角になるため に, 非踏み込み時には背屈位を保つ必要がある。これが 提案姿勢でのペダル操作を困難にしている理由であると 考えられる。

\section{5. 提案条件の評価}

\section{5-1. 着座感の評価}

提案した運転姿勢と従来の運転姿勢で, 表 1 (e)の男性

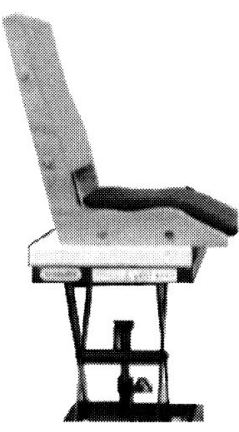

(a) 試作シート

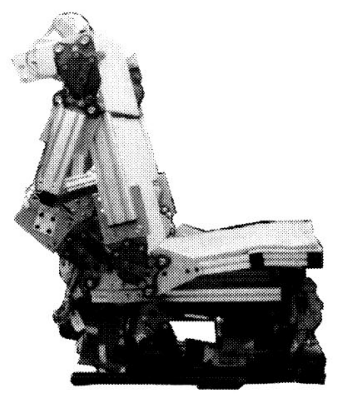

（b）比較用自動車シート
図 19 試作シートと比較用自動車シート

Fig. 19 Proto-type seat and driving seat for comparison.

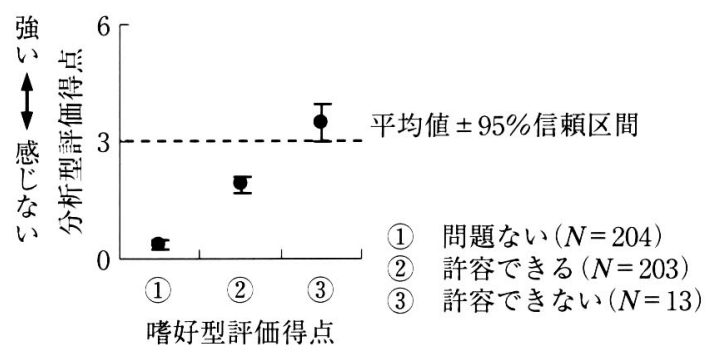

図 20 嗜好型評価得点と分析型評価得点の関係

Fig. 20 Relationship between preference value and analytycal value.

4 名, 女性 3 名に 1 時間の模擬運転を行わせ，官能検査 を行った。提案条件は図 19 (a)に示す試作シートで再現 し，比較用には，配送に使用されることの多いミニバン クラスの車両を参考に, 坐骨結節高さ $300 \mathrm{~mm}$, 背もた れ角度 $75^{\circ}$ ，座面角度 $5^{\circ}$ に設定した図 19 (b)の実験用自 動車シートを用いた。シート面は両条件共に剛体支持面 に厚さ $20 \mathrm{~mm}$ のウレタンクッションを貼り付けたもの である。従来条件では，ステアリングと下肢によるぺダ ル操作とした。一方，提案条件では，前述のようにペダ ル操作には適していない.このため, 暫定措置としてス テアリングの 10 時 10 分位置にポテンショメータ式ス イッチを取り付け, 右母指でアクセル, 左母指でブレー キ操作を行うものとした. ゲーム中のステアリング操作 角度は左右 $180^{\circ}$ 以下であるために，この操作方法でも 問題はなかった。

計測開始後は着座姿勢を自由に変えてよいものとし， 官能検查を計測開始時から 15 分おきに 5 回行った。官 能検査は, 痛みと疲労感について, [0（感じない）〜 6 (強く感じる) ] とする分析型 7 段階評価, およびその 痛みと疲労感について [問題ない〜許容できる〜許容で きない）とする嗜好型 3 段階評価とし，口頭質問形式で 行った。また, 着座時の安定感と疲労感の指標とし 
$\tau^{17}$ ，骨盤傾斜角度変動を小型傾斜計（緑測器製 UA-1）によりサンプリング周波数 $1 \mathrm{~Hz}$ で計測した。 傾斜計は右腸骨稜にゴムベルトを用いて固定した。

嗜好型 3 段階評価延べ 420 項目に対する，分析型評価 得点の分布を図 20 に示す。「許容できない」の $95 \%$ 信 頼区間を考慮しても，分析型評価得点が 3 以下であれば 十分許容できる範囲であることがわかる。

主な分析型官能検査結果を図 21 に示寸。図 21 の点線 は，許容限界である。背もたれに関する腰部と背部は， 従来運転姿勢とほぼ同様の高い評価を得た。一方，臂 部，大腿，および下肢の負担については，提案条件のほ うが劣り, 被験者 3 名が 45 分経過後の䌓部と大腿部の
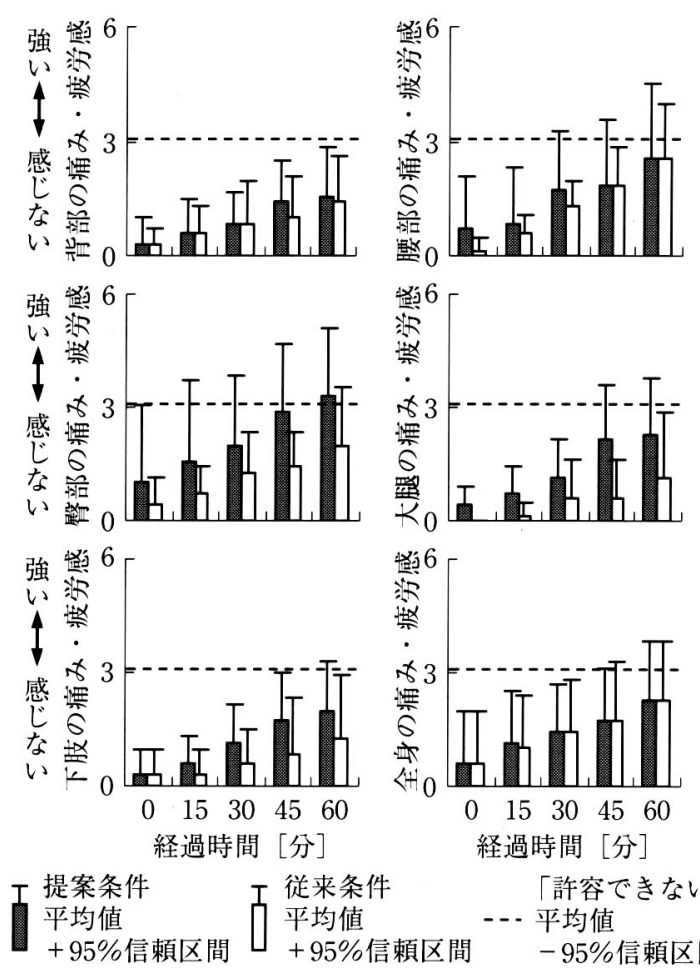

$+95 \%$ 信頼区間 +95\%信頼区間 $\quad-95 \%$ 信頼区間

図 21 着座感の官能検査結果

Fig. 21 Sensory value of seating comfort.

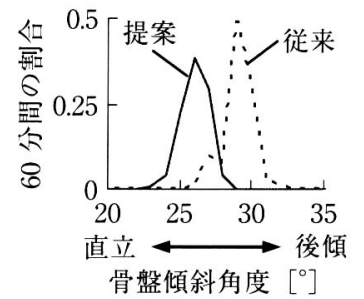

(a) 骨盤傾斜角度の ヒストグラム

図 22 姿勢変動量の比較

Fig. 22 Comparison of postural change.
痛みを許容できないとした。しかし，提案条件の 30 分 経過後の痛み・疲労感の評価は, すべて許容レベルより も有意に低かった $(p<0.05)$.このため, 少なくとも 都市部での宅配を想定した 15 分程度の連続着座 ${ }^{1)}$ では, 提案条件でも十分快適性を保証できると考えられる。さ らに, 総合的な全身の痛みと疲労感は 60 分後でも従来 運転姿勢と変わらなかった。なお, 本実験ではシート形 状を評価するために，両シートともクッションを薄くし た。したがって,クッションが厚い実用シートでは痛み の発生はさらに少ないと考えられる。

骨盤傾斜角度のヒストグラム例を図 22 (a)に示す。骨 盤傾斜角度は，あらかじめ取得した自然立位時の骨盤角 度との相対角度としたため, 平均值の違いは運転姿勢の 直立と後傾の差になっている，標準偏差は体動を示し， 疲労や圧迫を緩和するための姿勢変化や着座時の安定度 を表す ${ }^{17)}$. 骨盤傾斜角度の 60 分間の標準偏差を姿勢変 動量とすると, 図 22 (b)に示すように両条件で有意差は なく，着座の安定性は同等であった。

\section{5-2. 乗降動作負担の評価}

乗降動作の負担を評価するために，表 1 (f)の被験者 3 名に対し，筋電計（日本光電製 MEB-5508）を用い, 春柱起立筋と左右脚の内側広筋, 前脛骨筋 ${ }^{18)}$ の筋電を サンプリング周波数 $1,000 \mathrm{~Hz}$ で計測した。筋電波形は Bryantfilterにより遮断周波数 $5 \mathrm{~Hz}$ で平滑化し，あら かじめ取得した各被験筋の最大筋力時の筋電により基準 化した。計測条件は，5-1節と同様の提案シートおよび 従来シートとし，フロア段差は現行自動車の最低水準を 参考に $200 \mathrm{~mm}$ とした。計測動作はシート左側からの 乗車と降車とし, 休憩をはさみつつ各条件につき 3 回
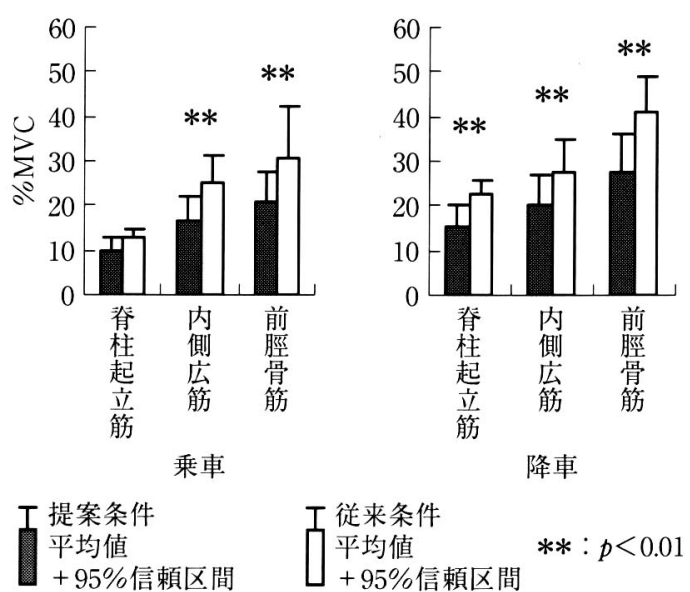

図 23 乗降動作時の最大発揮筋力

Fig. 23 The maximum muscular power at Ingress/Egress motion. 
行った.

乗降動作時の最大発揮筋力を図 23 に示す. 乗降動作 では, 左右脚の運動が異なるため, 内側広筋と前脛骨筋 については左右の最大筋力の平均值とした。 その結果, 提案条件ではもともと活動の少ない乗車時の脊柱起立筋 以外で, 筋負担が有意に減少し, 従来条件と比較して乗 車，降車ともに 3 割程度小さくなった。

\section{6. おわりに}

宅配など, 短時間で乗降を繰り返す断続的自動車運転 時の身体負担を軽減するために，立位と座位の中間的な 安定姿勢とそのための身体支持条件を探索した。 その結 果，座面高を股下高の $65 \%$ にして剧部を水平に支持し， 大腿部を傾斜させた中折座面が快適性の維持と乗降時の 筋負担低減に有効であることがわかった。ただし，この 座面条件ではぺダル操作に代わる新たな制御装置が必要 になり，また，安全対策など，今後の技術課題も多い。 一方, 本研究で示したシートの設計条件は, 日常的買い

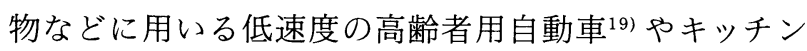
チェア, 空口業務用椅子など, 他の断続的着座用椅子に も応用できる可能性がある。

謝辞 本研究の一部は, 日産自動車侏の補助を受け た。ここに記して謝意を表す。

\section{参考文献}

1）運輸低公害車普及機構：「地域内物流共同輸配送への 低公害車導入促進事業」報告書, 日本財団図書館 (http://nippon.zaidan.info/index.html), 1998.

2）高木英匡：宅配用車両の現状と将来，自動車技術， 38(1), 52 58, 1984.

3) J. J. Congleton: The design and evaluation of the neutral posture chair for surgeons, Human Factors, $27(5), 589 \sim 600,1985$.

4）吉藤宏哉, 村 勲, 松井利樹, 森 健一：立与作業用椅
子の有無における生体諸機能と産業疲労, 人間工学, 34 (特別号), 236〜237, 1998.

5) M. R. Chester: Leg swelling, comfort and fatigue when sitting, standing, and sit/standing, Industrial Ergonomics, 29 (5), 289〜296, 2002.

6）高木 啓：勇気ある個性派集合, Car Styling, 28(4), 33 35, 2000 .

7) P. Arborelius: The effect of armrests and high seat heights on lower-limb joint load and muscular activity during sitting and rising, Ergonomics, 35 (11), 1377 1391, 1992.

8）安藤敏弘, 堀部 哲, 田中泰斗, 坂東直行: 人体負荷を 考慮した家具の最適設計 (第 1 報)，岐阜県生活技術研究 所研究報告, 5, 19 25, 2003.

9) R. F. Chander: Investigation of inertial properties of the human body, Wright-Patterson Aero Medical Research Laboratory, DOT-HS-017-2-315-1 A (AMRL-TR-74-137), 1975.

10) Gorge $C$ Marshall Space Flight Center: Man/System requirements for weightless environments, NASA, MSFC-STD-512 A, 1976.

11）社人間生活工学研究センター：日本人の人体計測デー 夕, 1997 .

12）山崎信寿, 佐々木貴弘, 相沢淳平：個別適合条件の探索 を目的とした可変クッション椅子の開発, 人間工学, 33(4), 211 218, 1997.

13）山崎信寿, 諸永裕一：短時間休息用剛体支持面安楽寝 椅子の形状適合化, 人間工学, 36(1), 29 37, 2000 .

14）D. Sinclair 著, 市岡正道訳：皮虐感覚, 医歯薬出版, 269, 1967.

15）間田直幹ら：新生理学(上)一動物的機能偏一, 第 3 版, 医学書院, 615 616, 1972.

16）相澤淳平, 平尾章成, 山崎信寿 : 背面形状計測装置の開 発と評価, 人間工学, 34 (特別号), 350 351, 1998.

17）吳 奇勲, 野呂影勇, 宮本博幸: 作業時のマイクロムー ブメントに関する研究, 人間工学, 30 (5), 315〜321, 1994.

18）中本一彦, 渥美文治, 小寺治行, 金森 等：快適な車内 空間 乗降時の筋負担定量化研究, Toyota Technical Review, 54 (2), 20 25, 2006.

19）鎌田 実, 山崎一平：新しい高齢者対応型車両開発の 研究, 長寿科学総合研究, 1997 (8), 173 179, 1998. 